\title{
FirSt RePORT OF LITOMOSA SPP. (NemATOdA: FILARIOIDEA) FROM MALAGASY BATS; REVIEW OF THE GENUS AND RELATIONSHIPS BETWEEN SPECIES
}

\author{
MARTIN C.*, BAIN O.*, JOUVENET N.***, RAHARIMANGA V.***, ROBERT V.***,***** \& ROUSSET D.***
}

\section{Summary:}

The presence of the filarial genus Litomosa in Malagasy bats is demonstrated by the finding of L. goodmani n. sp. from Miniopterus gleni and Litomosa sp. (male unknown) from M. manavi, both in the Special Reserve of Ankarana. These materials are compared to the 22 Litomosa species, including two Indian species originally placed in the genus Litomosoides, L. fotedari (Gupta \& Trivedi, 1989) n. comb. and L. tewarii (Gupta \& Trivedi, 1989) n. comb., and the new taxon L. seurati n. sp. (= L. beaucournui Bain, 1966 pro parte), type-host Rhinolophus ferrum-equinum, Algeria, distinguished by the narrow area rugosa and the female caudal extremity with two conspicuous points, instead of several small ones. The Malagasy material belongs to a group of species close to the type, L. filaria, which have a male area rugosa composed of cuticular bosses and microfilariae folded within the sheath, and which are parasitic in Vespertilionidae, Hipposideridae and Rhinolophidae from Africa and Europe. The two Malagasy species resemble L. seurati n. sp., L. beshkovi Jancev, 1971, L. chiropterum Ortlepp, 1932, L. adami Petit, 1980 and L. Ottavianii Lagrange et Bettini, 1948, with the enlarged third segment of the buccal capsule. L. goodmani n. sp. is distinct with its small size and female caudal extremity with a single point, which is suppressed in old mature worms; the females of Litomosa sp. have two conical points. Relationships among Litomosa species appear to be dependent upon both the chiropteran host groups and the geographical region.

KEY WORDS : Filariae, Litomosa, bats, Madagascar, new species
Résumé : Présence de Litomosa SPP. (Nematoda: Filarioidea) CHEZ Des Chauves-SOURIS MALGaCHES; RÉVISION DU GENRE ET RELATIONS ENTRE LES ESPÈCES

Mise en évidence de Filaires du genre Litomosa chez des Chauvessouris malgaches endémiques avec la description de Litomosa goodmani n. sp. chez Miniopterus gleni et Litomosa sp. (mâle inconnul chez M. manavi, provenant de la Réserve Spéciale d'Ankarana. Ces matériels ont été comparés aux 22 espèces incluses dans le genre, compte-tenu de deux espèces indiennes décrites comme Litomosoides, L. fotedari (Gupta \& Trivedi, 1989) n. comb. et L. tewarii (Gupta \& Trivedi, 1989) n. comb., ainsi que du nouveau taxon L. seurati n. sp. (= L. beaucournui Bain, 1966 pro parte), hôte type Rhinolophus ferrum-equinum, Algérie, distinct par l'area rugosa étroite et l'extrémité caudale de la femelle avec deux pointes, au lieu de plusieurs petites. Les matériels malgaches appartiennent au groupe qui comprend l'espèce type L. filaria, dont l'area rugosa est composée de perles cuticulaires et la microfilaire pliée dans la gaine, et qui sont parasites de Vespertilionidae, Hipposideridae et Rhinolophidae en Afrique et Europe. Avec une capsule buccale à grand segment 3, elles sont proches de L. seurati n. sp., L. beshkovi Jancev, 1971, L. chiropterum Ortlepp, 1932, L. adami Petit, 1980 et L. ottavianii Lagrange et Bettini, 1948 L. goodmani n. sp. est distinct par sa petite taille et par l'extrémité caudale de la femelle à pointe unique qui régresse chez les vers âgés; les femelles de Litomosa sp. ont deux pointes séparées. Les relations entre les espèces du genre Litomosa dépendent à la fois des groupes de Chiroptères-hôtes et des localisations géographiques.

MOTS CLÉS : Filaires, Litomosa, chiroptère, Madagascar, nouvelle espèce.

\section{INTRODUCTION}

$\mathrm{F}$ ilarial worms in Madagascar, as well as other nematode parasites, were studied primarily during the period 1955-1975. Investigations focu-

\footnotetext{
* USM 307, Parasitologie comparée et Modèles expérimentaux, associée à l'INSERM U567, Muséum National d'Histoire Naturelle, 61, rue Buffon, 75231 Paris Cedex 05, France.

*** Aaron Diamon AIDS Research Center, Rockefeller University, 455 First avenue, New York, NY 10016, USA.

**:* Groupe de recherche sur le paludisme, Institut Pasteur de Madagascar, BP 1274, Antananarivo 101, Madagascar.

***** UR-77, Paludisme afrotropical, Institut de Recherche pour le Développement (IRD), France.

Correspondence: Odile Bain.

Tel.: 33 (0)1 40793497 - Fax: 33 (0)1 40793499.

E-mail: bain@mnhn.fr
}

sed on lemurians, insectivores (= lipotyphlans), birds, reptiles, and frogs (as examples, Chabaud et al., 1961; Chabaud et al., 1963; Bain \& Prod'hon, 1974). At that time no filaria had been reported in bats. However an important genus, Litomosa Yorke \& Maplestone, 1926 (Onchocercinae) is parasitic in Old World bats, and species are known from the Ethiopian region of Africa (Ortlepp, 1932; Bain, 1966; Petit, 1980).

Bats have been the least studied mammals of Madagascar (Andriamialiosa \& Langrand, 2003). Recently, as part of a comprehensive survey of Malagasy fauna, carried out by WWF and the Pasteur Institute of Madagascar, bats were trapped at several sites and examined for blood parasites. Some of them were found to harbour microfilariae (Raharimanga et al., 2003). A search for adult filariae was subsequently undertaken and several worm samples were recovered. They belonged 
to the genus Litomosa, because they had a segmented buccal capsule partly embedded in the oesophagus, and folded microfilariae (Chabaud \& Bain, 1976; Anderson \& Bain, 1976; Guerrero et al., 2002), characteristic of the type species and of many, but not all, other species of the genus. Study of the Malagasy material led to a comprehensive review of Litomosa and species relationships, on the basis of the available morphological data.

\section{MATERIALS AND METHODS}

A research licence was granted by the Ministère des Eaux et Forêts de Madagascar and by the Association Nationale pour la Gestion des Aires Protégées. The field research was directed by S.M. Goodman (Field Museum of Natural History, Chicago) with his collaborator S.G.F. Cardiff (Columbia University, New York). Bats for the present study were trapped in caves, rarely forest, at Andrafiabe, Special Reserve of Ankarana, Antsiranana Province, $12^{\circ} 55^{\prime} \mathrm{S}$, $49^{\circ} 03^{\prime} \mathrm{E}$, at 40 metres altitude, during May 2003. Each collected bat was given a field catalogue number beginning with the acronym SMG. Bats were necropsied at the field site. Thick smears of an undetermined small volume of blood were prepared and stained with Giemsa (Raharimanga et al., 2003). Recovered worms were fixed in 90 per cent alcohol. Hosts are named according to Wilson \& Reeder (1993) and Peterson et al. (1995).

Some type specimens of Litomosa species were re-examined by two of us (OB \& NJ): L. maki Tibayrenc, Bain \& Ramachandran, 1979 from the collection in the Muséum National d'Histoire Naturelle, Paris (MNHN) (number $213 \mathrm{JE}$ ), L. miniopteri Mackerras, 1962, from the South Australian Museum (a male and a female paratypes, number 3994), L. americana McIntosh, 1932 U.S. National Parasite Collection (male paratype number T122-F; 15124)

For the morphological study, worms were cleared in lactophenol and drawn with the aid of a microscope equipped with a camera lucida. An apical view of the head was prepared, as in previous work (Bain \& Guerrero, 2003). The male posterior part was examined with particular emphasis on the ventral cuticular ornamentation, the area rugosa (Bain, 1966). Microfilariae were extracted from female uteri, near the vagina. Buccal capsule length and maximum external diameter were measured, and capsule segments numbered according to Bain (1966). The tail ratio, length/width at the level of the anus, was determined. Measurements are given in $\mu \mathrm{m}$, except for the body length, which is given in millimetres. The authorities of the new taxa described below are Martin \& Bain.

\section{RESULTS}

Dilariae were recovered from two species of ves$\checkmark$ pertilionids, Miniopterus gleni Peterson, Eger \& 1 Mitchell and M. manavi Thomas. The material from M. gleni comprised male and female worms and represented a new species. Female worms, but no male, were recovered from $M$. manavi; they were studied but no specific identification could be made. Circulating microfilariae were found only in $M$. manavi blood smears.

\section{LITOMOSA GOODMANI N. SP. MARTIN \& BAIN}

\section{STUDIED MATERIAL}

Filariae, and a few filarial granulomas, were recovered from five M. gleni among ten captured, in forest (SMG 13710) and caves (all others). The studied material comprised one female worm with microfilariae (MNHN number 453 SE, male bat SMG 13710); one juvenile female worm, two long posterior parts of female without microfilariae ( 455 SE, female bat SMG 13743); two female worms with microfilariae, one male, two female filarial granulomas (456 SE, female bat SMG 13744); two female worms with microfilariae, two males ( 457 SE, male bat SMG 13746); and a filarial granuloma (458 SE, male bat SMG 13747). Worms were located in the abdominal cavity, mostly dorsal to the liver. Host cells were attached to the body cuticle of a few worms (two females 453 SE and 456 SE and one juvenile $455 \mathrm{SE}$ ); the cells were either scattered or formed a more or less continuous thin layer and were removed from the worm with a fine brush. The worms are illustrated in Figure 1; individual measurements are reported in Tables I and II, and means \pm standard error of the mean in the text.

\section{- Female (Fig. 1 A-J; Table I)}

Maximum body width in anterior part. Body cuticle with lateral internal thickening. Shoulder-shaped apex. Head with one apical circle of four papillae and amphids, all minute, similar. Mouth minute; buccal capsule segmented, with segment number 3 larger; in one paratype specimen, segment 3 with anteriorly directed external crest (named horn in Petit, 1980); buccal cavity rhomboidal in longitudinal section; buccal cavity and capsule round in transverse section. Nerve ring far from head. Oesophagus short, with Y-shaped lumen in transverse section; no glandular part. Vulva near oesophageal-intestinal junction, anterior or posterior to it; vagina subspherical or elongated, with S-shaped lumen, chamber closed posteriorly by cellular sphincter. Length of unpaired ovejector not determined. Opisthodelphous; uteri tightly coiled, extending almost to head when filled with microfilariae (in such worms, position of nerve ring not determined; see Table I). Tail 


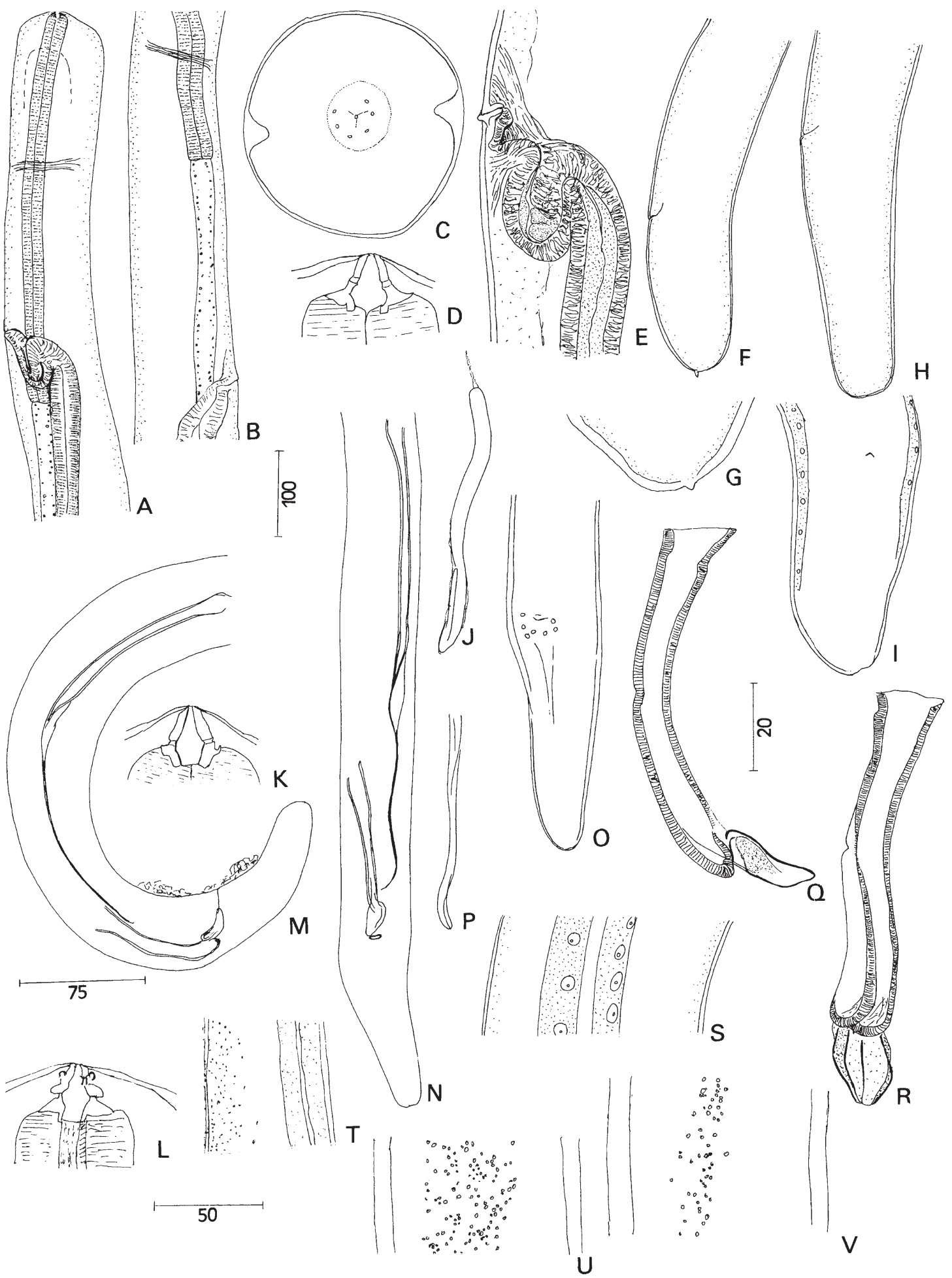

Fig. 1. - Litomosa goodmani n. sp. A to J: Female; A. Anterior part of a juvenile female, left lateral view (456 SE); B. Idem, mature female, right lateral view ( $456 \mathrm{SE}$ ); C. Head, apical view (paratype); D. Buccal capsule, median view (same paratype); E. Vagina, left lateral view (456 SE); F. Tail, left lateral view, juvenile ( $455 \mathrm{SE}$ ); G. Caudal extremity of another juvenile, ventral view (456 SE); H. Tail, left lateral view, mature female ( $455 \mathrm{SE}$ ); I. Tail, ventral view, another mature female ( $456 \mathrm{SE}$ ); J. Uterine microfilaria ( $453 \mathrm{SE}$ ). K to V: Male; K. Buccal capsule, segment 3 with horn, lateral view (paratype); L. Head papillae, amphid, and buccal capsule, lateral view (456 SE); M. Posterior end, right lateral view (paratype, with host-cells attached on the ventral side); N. Posterior end, ventral view (allotype); O. Tail, ventral view (allotype); P. Left spicule, distal extremity, lateral view (paratype); Q-R. Right spicule, right lateral view and dorsal view, respectively (paratype); S. Lateral chord, lateral view (456 SE); T. Area rugosa at its mid-length and lateral chord, left sublateral view (paratype); U. Detail of area rugosa at its mid-length, ventral view (paratype); V. Posterior part of area rugosa, ventral view. Scales in $\mu \mathrm{m}$ : A, B = 100; C, E, $\mathrm{O}, \mathrm{T}=50 ; \mathrm{D}, \mathrm{G}, \mathrm{J}, \mathrm{K}, \mathrm{L}, \mathrm{P}, \mathrm{Q}, \mathrm{R}, \mathrm{S}, \mathrm{U}, \mathrm{V}=20 ; \mathrm{F}, \mathrm{H}, \mathrm{I}, \mathrm{M}, \mathrm{N}=75$. 


\begin{tabular}{|c|c|c|c|c|c|c|c|}
\hline Specimens & $\begin{array}{c}\text { Holotype } \\
457 \text { SE-1 }\end{array}$ & $\begin{array}{l}\text { Paratype } \\
\text { 457 SE-2 }\end{array}$ & $\begin{array}{c}\text { Other } \\
456 \mathrm{SE}-1\end{array}$ & $\begin{array}{l}\text { Other } \\
456 \mathrm{SE}-2\end{array}$ & $\begin{array}{c}\text { Other } \\
455 \text { SE-1 }\end{array}$ & $\begin{array}{c}\text { Other } \\
455 \mathrm{SE}-2\end{array}$ & $\begin{array}{c}\text { Other } \\
455 \text { SE-3 }\end{array}$ \\
\hline Length $\mathrm{mm}$ & 28 & 21.5 & 19.5 & 25.5 & 23.86 & ND & 17.25 \\
\hline Width $\mu \mathrm{m}$ & 130 & 120 & 125 & 120 & 150 & 140 & 120 \\
\hline Buccal caps L/W & $18 / 20.5$ & $15 / 19$ & $15 / 20.5$ & $12 / 20$ & ND & ND & $13 / 19$ \\
\hline Nerve ring & 240 & 180 & 180 & 280 & 210 & ND & ND \\
\hline Oesophagus & 460 & 430 & 460 & 420 & 430 & ND & 480 \\
\hline Vulva & 510 & 510 & 390 & 710 & 500 & ND & 480 \\
\hline Tail L/w & $145 / 65$ & $115 / 70$ & ND & $160 / 60$ & ND & $130 / 80$ & $90 / 60$ \\
\hline mid tail $\mathrm{w}$ & 55 & 60 & ND & 50 & ND & 75 & 52 \\
\hline Caudal point & 0 & 0 & 1 & 0 & 0 & 0 & 1 \\
\hline Microfilaria & yes & yes & yes & yes & no & no & no \\
\hline
\end{tabular}

Table I. - Litomosa goodmani n. sp.; measurements of females.

short, thick, almost cylindrical, sometimes slightly expanded at extremity, straight or slightly bent dorsally; tail ratio about 2 (1.5 to 2.66); caudal extremity rounded and smooth in mature long females, with one terminal axial point in juvenile and mature short females. Mean measurements: body length $23 \pm 1.5$, width $129.3 \pm 4.42$, nerve ring $218 \pm 19$ from apex, oesophagus $450 \pm 10.9$ long, vulva $516.7 \pm 42.9$ from apex, tail $128 \pm 12.1$, tail ratio $1.93 \pm 0.22$.

Microfilariae from uteri (female $453 \mathrm{SE}$ ): 94-108 $\mu \mathrm{m}$ long; maximum width near head $4-4.5 \mu \mathrm{m}$, body gradually attenuated to tail; posterior third of body folded inside short sheath. Very small cephalic hook.

- Male (Fig. $1 \mathrm{~K}-\mathrm{V}$; Table II)

Buccal capsule as in female; segment 3 with horn in one of the three males (paratype); segment 2 also enlarged in one male (456 SE). Testis extended far anteriorly, near buccal capsule. Area rugosa anterior to cloacal aperture, 800 to 1,900 from tail tip, composed of wide band of tiny cuticular bosses, irregularly and densely distributed; band narrower at both extremities of area. Caudal papillae minute, not numerous, arranged in rectangle composed of one precloacal right papilla (left papilla of the pair is lacking), one paracloacal pair, two postcloacal pairs almost aligned transversely; no papilla near caudal extremity. Left spicule

\begin{tabular}{lccc}
\hline \multicolumn{1}{c}{ Specimens } & $\begin{array}{c}\text { Allotype } \\
\text { 457 SE-2 }\end{array}$ & $\begin{array}{c}\text { Paratype } \\
\text { 457 SE-1 }\end{array}$ & $\begin{array}{c}\text { Other } \\
\text { 456 SE-1 }\end{array}$ \\
\hline Length mm & 12.3 & 13.5 & 12.8 \\
Width $\mu \mathrm{m}$ & 85 & 95 & 105 \\
Buccal caps L/w & $12 / 15$ & $15.5 / 15$ & $13 / 18$ \\
Nerve ring & 200 & $\mathrm{ND}$ & 170 \\
Oesophagus & 370 & 350 & 365 \\
Left sp (handle) & $300(160)$ & $265(140)$ & $305(175)$ \\
Right sp & 105 & 100 & 112 \\
Tail L/w & $105 / 45$ & $90 / 35$ & $95 / 40$ \\
$\quad$ mid tail w & 32 & 30 & 30 \\
Area rugosa & $\mathrm{ND}$ & $800-1,900$ & $770-\mathrm{ND}$ \\
\hline
\end{tabular}

sp, spicule; caps, capsule.

Table II. - Litomosa goodmani n. sp.; measurements of males. with handle equal to half spicule length, long thin intermediary piece and filamentous lamina (flabellum). Right spicule complex: tubular part with prominent dorsal heel distally; terminal spoon-shaped piece with well-sclerotized lateral edges.

Mean measurements: body $12.9 \pm 0.35$ long, $95 \pm 5.8$ wide, oesophagus $362 \pm 6$ long, tail $96.6 \pm 4.4$ long, tail ratio $2.42 \pm 0.07$, left spicule $290 \pm 12.6$ long (handle $158 \pm 10.1$ ), right spicule $105.7 \pm 3.5$.

\section{DisCUSSION}

The Malagasy material was compared to all species included in the genus Litomosa. These are all parasitic in bats except two species from North American geomyoid rodents, originally placed in the similar New World genus Litomosoides Chandler, 1931, and recently transferred to Litomosa on the basis of morphological features (Guerrero et al., 2002). The type-host and geographical origin are indicated for each species.

Four species differ greatly from our material since they have no area rugosa and have several other distinctive characters. L. americana McIntosh, 1932 from Nycticeius humeralis (Rafinesque), Washington, USA, studied in detail by McIntosh \& McIntosh (1935) and re-examined, is very peculiar with a large oval mouth, dorso-ventrally flattened buccal capsule without a posterior part inserted in the oesophagus, a vulva close to nerve ring, and unfolded microfilariae. L. miniopteri Mackerras, 1962, from Miniopterus schreibersi (Kuhl), Australia, re-examined, has a short buccal capsule $5 \mu \mathrm{m}$ long, a less complex extremity of the right spicule, and differently shaped male and female tails. L. aelleni Tibayrenc, Bain \& Ramachandran, 1979 from Tadarida taeniotis Rafinesque, Switzerland, has a divided oesophagus, a short right spicule $(40-45 \mu \mathrm{m})$ with a simple extremity, female and male tail extremities with two large lappets, and unfolded microfilaria. L. japonica Ohbayashi \& Kamiya, 1979 from Vespertilio orientalis Wallin, Japan, has a very long undivided oesophagus, a simple right spicule, no points on female and male tail extremities. 
A group of three similar species, of which the area rugosa and microfilariae were not studied, are also distinct, with a long thin tail in the female (tail ratio 8) and vulva far posterior to the oesophageal-intestinal junction. These species are L. jairajpuri Trivedi \& Gupta, 1989 from Hipposideros pallidus Blyth, and L. fotedari (Gupta \& Trivedi, 1989) n. comb. and L. tewarii (Gupta \& Trivedi, 1989) n. comb., which were originally assigned to the genus Litomosoides, and are respectively parasitic in Taphozous melanopogon Temminck and Megaderma lyra Temminck. They are all from Rajasthan, India.

L. vaucheri Petit, 1980 from V. murinus Linnaeus, Switzerland, and the similar species Litomosa sp. Ohbayashi \& Kamiya, 1979, from $V$. orientalis, Japan, both known only by a female without microfilariae, are distinct, with three prominent spindle-shaped caudal points and tail ratios of 4 and 3.5, respectively.

Four species have an area rugosa, composed of transverse bands of short longitudinal crests. Additional distinctive characters are as follows: L. maki Tibayrenc, Bain \& Ramachandan, 1979 from Pteropus vampyrus Linnaeus, Malaysia, re-examined, has an attenuated anterior extremity, less reduced set of caudal sensory papillae (three pairs of distinctly precloacal papillae in addition to 2-3 postcloacal pairs), truncated caudal extremity with 3-4 lateral and median points in both sexes, and a simple right spicule, microfilariae are unknown. L. thomomydis (Gardner \& Schmidt, 1986) and L. westi (Gardner \& Schmidt, 1986), from geomyid rodents, Colorado, USA. (Guerrero et al., 2002), have a tiny buccal capsule $(7-9 / 11 \mu \mathrm{m})$, rare cloacal papillae, and one and three caudal prominent points in the respective females; both also have a vulva far posterior to the oesophagus and a thin long tail (tail ratio 8-9). L. dogieli Bogdanov \& Vladimirov, 1956 (in Sonin, 1975) from Myotis emarginatus E. Geoffroy, Europe, redescribed by Desportes (1946) as L. filaria (v. Beneden, 1872), by Bain (1966) as L. desportesi Bain, 1966, and similarly by Petit (1980), has a shoulder-shaped anterior extremity and complex right spicule similar to the present material, but it has caudal papillae aligned on the tail instead of being grouped near the cloaca; the female tail ratio is 4 , its round posterior extremity has a conspicuous transverse furrow and two tiny lappets; the buccal capsule is subspherical; and the folded microfilariae are longer and thinner than in our material $(124-145 / 4 \mu \mathrm{m})$.

The next group of species, which includes the type L. filaria (v. Beneden, 1872), has an area rugosa composed of cuticular bosses, a few caudal papillae placed near the cloacal aperture, complex right spicule and shoulder-shaped anterior extremity like our specimens. Two species for which the important male characters, area rugosa and caudal papillae, have not been described, are however placed in this group because of their general resemblance (they are indicated in the text with an asterisk). L. hugoti Petit, 1980, from Rhinolophus sylvestris Aellen, Gabon, has two equally enlarged segments (numbers 2 and 3) in the buccal capsule, a set of four external papillae and four cephalic papillae, and a curved female tail with two terminal points (Petit, 1980). L. pujoli Bain, 1966, from Hipposideros cyclops Temminck, Gabon, has a tubular buccal cavity and a small segment 3, caudal papillae placed in a postcloacal half-circle, female tail constricted subterminally with a rounded slightly trifid extremity, and male tail with two terminal points (Bain, 1966; Petit, 1980). L. skarbilowitchi* Petrov et Tschertkova, 1954, from Rhinolophus clivosus Cretzschmar ( $R$. bocharicus in the original description), Uzbekistan, has a long tubular buccal cavity with a long segment 4 embedded in the oesophagus and moderately enlarged segment 3 , large left and right spicules (541 and $151 \mu \mathrm{m}$ respectively), and female tail with two jointed terminal points (Petrov \& Tschertkova, 1954, in Sonin, 1975). L. filaria, parasite of Plecotus auritus Linnaeus, Europe, redescribed by Bain (1966) and Petit (1980) from the same host, has a bottleshaped buccal cavity, segment 3 of moderate size, short female tail bent ventrally, and a subterminal group of four, rarely two, close points which are sharp or smooth. L. beshkovi Jancev, 1971, from Vespertilio nathusii Keyserling \& Blasius, Bulgaria, has a bucccal capsule with a large segment 3 like our specimens, but the buccal cavity is not constricted anteriorly, the left spicule is longer $(355 \mu \mathrm{m})$, and the female tail has numerous small terminal points (Jancev, 1971). The final four species, also with a buccal capsule with a large segment 3 , have a bell-shaped buccal cavity with a minute mouth. They are distributed in two regions and are the closest species to the Malagasy material. . i) From European and Mediterranean areas, L. ottavianii Lagrange \& Bettini, 1948 appears to be a complex of two species. It was described from Vespertilio murinus(Linnaeus ) [more likely Myotis blythii (Tomes) according to Lanza, 1999] and Miniopterus schreibersi (Kuhl), Sardegna, Italy (Lagrange \& Bettini, 1948). This species, studied in France from M. schreibersi (as L. beaucournui Bain, 1966, synonymized with L. ottavianii by Sonin, 1975), also occurred in Rhinolophus sp., but Bain (1966) noticed that the morphology was different in some geographical areas. Our present interpretation is that two species may infect rhinolophs and we propose the new species L. seurati n. sp. (= L. beaucournui Bain, 1966, pro parte), male type from Rhinolophus ferrum-equinum (Schreb.), Algeria, studied by Seurat (1921) and redescribed by Bain (1966). It is distinct from L. ottavianii, and from our material, with a narrow area rugosa, female tail with two separate conical points, and narrower buccal capsule (14-15 $\mu \mathrm{m}$; Bain, 1966). Litomosa seurati n. sp. is also parasitic in Rbinolophus spp. from Morocco and the south of France 
(Bain, 1966). L. ottavianii s. s. has similar microfilariae and male caudal papillae to the Malagasy specimens (Petit, 1980) but it is distinct as the adults are twice as long and the female tail has several small irregular points (Bain, 1966).

. ii) From tropical and equatorial Africa, L. adami Petit, 1980 from Miniopterus m. minor Peters, Gabon, has horns on the large segment 3, also observed in some of our specimens, but a wider buccal capsule $(25 \mu \mathrm{m})$, female tail with two separate conical points, and slightly shorter and wider microfilariae (78-93/6 $\mu \mathrm{m})$. L. chiropterum* Ortlepp, 1932 from M. schreibersi (M. natalensis in the original description), Republic of South Africa, is three times as long and has two terminal conical points on the female tail.

The filariae from $M$. gleni appear to be distinct from the known species and are named Litomosa goodmani n. sp.

\section{TAXONOMIC SECTION}

Type-host: Miniopterus gleni Peterson, Eger \& Mitchell, 1995, Vespertilionidae.
Type-locality: caves of Andrafiabe, Special Reserve of Ankarana, Province of Antsiranana, Madagascar. Coordinates $12^{\circ} 55^{\prime} \mathrm{S}, 49^{\circ} 03^{\prime} \mathrm{E}, 40$ metres altitude.

Site: abdominal cavity, dorsal to the liver.

Type-material: female holotype, male allotype, one female paratype, one male paratype, from a male $M$. gleni number SMG 13746, deposited in the Muséum National d'Histoire Naturelle, Paris (MNHN), no. 457 SE.

Other material in MNHN collection: one male and two females (456 SE), one dissected female (453 SE), two females and one posterior part of female ( $455 \mathrm{SE}$ ).

Prevalence: $50 \%(5 / 10)$.

Etymology: the species Litomosa goodmani n. sp. is dedicated to Dr Steven M. Goodman, who directed the fieldwork.

\section{LITOMOSA SP. FROM M. MANAVI}

\section{SUDIED MATERIAL}

One female with a few microfilariae but numerous developing microfilarioid embryos (451 SE, bat SMG 13702); one female with developing microfilarioid

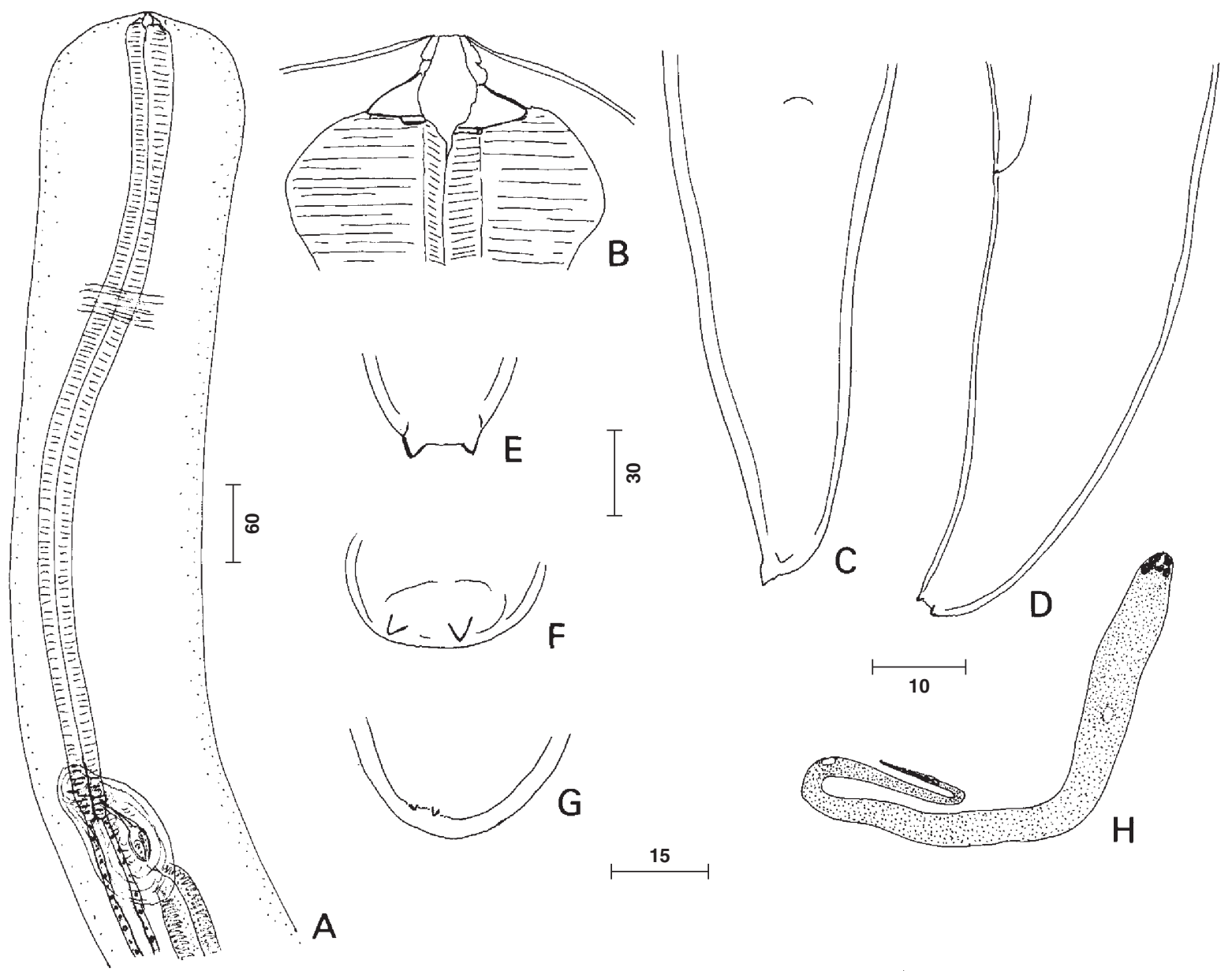

Fig. 2. - Litomosa sp. from M. manavi, female. A-E, 451 SE: A. Anterior end, dorsal view; B. Buccal capsule; C \& D. Tail, ventral view and left lateral view at anus, becoming lateral and ventral at extremity, respectively; E. Caudal extremity, ventral view; F \& G. Caudal extremity, ventral view, females $452 \mathrm{SE} ; \mathrm{H}$. Microfilaria from a blood smear (452 SE). Scale in $\mu \mathrm{m}$ : A = 60; B, E, F, G, = 15; C, D = 30; H = 10. 
embryos, one posterior part of female (452 SE, bat SMG 13703); a blood smear with microfilariae. Both bats were captured in forest. A third $M$. manavi, from a cave, was infected but only a fragment of one female was recovered (454 SE, bat SMG 13714).

Description of female (Fig. 2A-H) and measurements (451 SE, 452 SE): body 45 and 45.8 long, maximum width 150 and 120 in anterior part; buccal capsule 16/28 and 15/28; segment 3 larger; buccal cavity rhomboidal, nerve ring 230 and ND from apex; oesophagus 650 and 525; vulva 580 and 765 from apex; tail 185, 240 and 110, conical ( $451 \mathrm{SE}$ ) or not attenuated (452 SE), slightly bent ventrally or straight, with two conical salient points ( $451 \mathrm{SE}$, entire female $452 \mathrm{SE}$ ) reduced in one specimen (posterior fragment $452 \mathrm{SE}$ ); microfilariae extracted from uterus broken, length not measurable, maximum width $6 \mu \mathrm{m}$; microfilaria from a thick blood smear (452 SE, 13703) 76 long, maximum width 5 , progressively attenuated from postcephalic region to caudal extremity, posterior part folded once (illustration in Rahamiranga et al., 2003) or twice (Fig. 2H) in a shorter sheath.

The material parasitic in M. manavi is similar to L. goodmani $\mathrm{n}$. sp. but does not seem to belong to the same species: the caudal points are paired, not single; segment 3 of the buccal capsule is proportionally larger; and the mature females are longer.

No distinct characters separate this material from L. chiropterum, parasitic in $M$. schreibersi in South Africa, given the present state of knowledge of both lots of specimens.

At Ankarana, blood microfilariae were detected in 1/10 M. manavi. Prevalence, based on unidentified blood microfilariae, reached $41.7 \%(25 / 60)$ in another protected area, Beamaraha (Raharimanga et al., 2003)

\section{CONCLUSION}

T This study revealed the presence of Litomosa on the island of Madagascar, as expected. The infected bats were two endemic species of miniopterans (Vespertilionidae). This is a small sample given that 30 species of chiropterans belonging to seven families are reported in Madagascar (Eger \& Mitchell, 2003). Of these families, species of Litomosa are known from the Molossidae, Hipposideridae and Pteropidae in Africa, Europe, Japan, Asia and India.

Some species of Litomosa have been recovered only once, and sometimes incompletely described. Others have been studied often, as in Europe, where precise morphological analyses have demonstrated considerable diversity and weak host-specificity (Bain, 1966); the host range is also determined by ecological factors (Hosek \& Horacek, 1989).

The genus Litomosa, in its present composition of 22 species, displays several morphological types, with inter- mediary forms. They seem to be associated with host group and host geographical distribution.

The species from Pteropidae, L. maki, seems to be the most primitive on the basis of its well developed set of caudal papillae; it is the only species known from Megachiropterans. The two Palearctic species, L. aelleni from molossids and L. japonica from vespertilionids also have some primitive features, such as the well developed oesophagus, simple right spicule and absence of the area rugosa. The European L. dogieli from vespertilionids and the two North American species from geomyids have the area rugosa composed of transverse bands of longitudinal crests and folded microfilariae, like the type species of Litomosoides and Litomosa, respectively. As emphasized by Guerrero et al. (2002), the history of Litomosa cannot be dissociated from that of the New World genus Litomosoides. The three Indian species, as well as the two Palearctic species L. vaucheri and Litomosa sp., all incompletely known, may have some relationship with this group because of the long thin female tail.

The last group of Litomosa, which includes the type species L. filaria, has an area rugosa composed of a wide band of cuticular bosses irregularly and densely distributed rather than transverse bands of short longitudinal crests. It is predominant in Africa and Europe and probably extends to Central Asia (Uzbekistan; L. skarbilowitchi). The Malagasy filariae belong to this group. Like their hosts $M$. gleni and $M$. manavi, which are close to African miniopterans, they have strong affinities with the African L. chiropterum and L. adami, themselves closely related to some of the North African and European species, L. beshkovi, L. seurati n. sp. and $L$. ottavianii from vespertilionids and rhinolophids.

L. miniopteri, a unique species described from Australia, is very different from this group, yet it is also a parasite of M. schreibersi, which suggests the existence of a particular regional fauna. Finally, L. americana, a parasite of vespertilionids, is very distinct and, like Josefilaria Moorhouse, Bain et Wolf, 1979, from Megadermatidae in Australia, may represent a distinct onchocercine genus.

\section{ACKNOWLEDGEMENTS}

W e thank Dr John Baker for revising the manuscript, Dr I. Whittington at the South Australian Museum and Dr P. Pillitt at the US National Parasite Collection for providing the type specimens.

\section{REFERENCES}

ANDRIAMIALIOSA F. \& LANGRAND O. The history of zoological exploration of Madagascar, in: The Natural History of Madagascar. Goodman S.M. \& Benstead J.P. (eds), The University of Chicago Press, Chicago and London, 2003, 1-15. 
Anderson R.C. \& Bain O. Diplotriaenoidea, Aproctoidea and Filarioidea, in: C.I.H. Keys to the Nematode Parasites of Vertebrates. Anderson R.C., Chabaud A.G. \& Willmott S.M. (eds), Commonwealth Institute of Helminthology, St. Albans (Herts.), UK, 1976, No 3, 59-116.

BaIn O. Diversité et étroite spécificité parasitaire des Filaires de chauves-souris, confondues sous le nom de Litomosa filaria (van Beneden, 1872). Bulletin du Muséum National d'Histoire Naturelle, Paris, 2e série, 1966 (1967), 38, 928939.

BAIN O. \& GuERrERo R. Bisbalia vossi n. g., n. sp. (Nematoda: Onchocercidae), a filarial worm from a geomyoid rodent, Heteromys anomalus, in Venezuela. Systematic Parasito$\log y, 2003,54,145-156$.

Bain O. \& Prod'HOn J. Homogénéité des Filaires de Batraciens des genres Waltonella, Ochoterenella et Madochotera; création des Waltonellinae n. sub. fam. Annales de Parasitologie Humaine et Comparée, 1974, 49, 721-739.

Beneden (v.) P.J. Les parasites de Chauves-souris de Belgique. Bulletin de l'Académie Royale de Belgique, 1872, 33, 207-209.

Chabaud A.G. \& Bain O. La lignée Dipetalonema. Nouvel essai de classification. Annales de Parasitologie Humaine et Comparée, 1976, 51, 365-397.

Chabaud A.G., Brygoo E.R. \& Durette M.C. Spirurides parasites d'Oiseaux malgaches. Annales de Parasitologie Humaine et Comparée, 1963, 38, 93-108.

Chabaud A.G., Petter A. \& Golvan Y. Les Nématodes parasites de Lémuriens malgaches. III. - Collection récoltée par M. et Mme Francis Petter. Annales de Parasitologie Humaine et Comparée, 1961, 36, 112-126.

Chandler A.C. New genera and species of nematode worms. Proceedings of the United States National Museum, 1931, 78, 1-11.

Desportes C. Des Filaires dans le tube digestif. Annales de Parasitologie Humaine et Comparée, 1946, 21, 138-141.

Eger J.L. \& Mitchell L. Chiroptera, Bats, in: The Natural History of Madagascar. Goodman S.M. \& Benstead J.P. (eds), The University of Chicago Press, Chicago and London, 2003, 1287-1298.

GARDNER S.L. \& SCHMIDT G. Two new species of Litomosoides (Nematoda: Onchocercidae) from pocket gophers (Rodentia: Geomyidae) in Colorado. Systematic Parasitology, 1986, 8, 235-242.

Guerrero R., Martin C., Gardner S.L. \& Bain O. New and known species of Litomosoides (Nematoda: Filarioidea): important adult and larval characters and taxonomic changes. Comparative Parasitology, 2002, 69, 177-195.

GuPTA S.P. \& TRIVEDI K.K. Nematode parasites of vertebrates. On two species of the genus Litomosoides Chandler, 1931 (Family: Dipetalonematidae Wehr, 1935) from microbat of Udaipur Rajasthan, India. Indian Journal of Helminthology, 1989, 41, Suppl. Fotedar Commemoration Volume, 152-161.

Hosek J. \& Horacek I. Nematodes parasitizing the Palearctic bats: host-parasite relations. European Bat Research 1987. Hanak V., Horacek I. \& Gaisler J. (eds), Charles Univ. Press, Praha, 1989, 465-473.

JANCEV J.I. Litomosa beshkovi n. sp. (Filariidae) of Vespertilio nathusii Keys and Bl. in Bulgaria. Comptes rendus de l'Académie bulgare des Sciences, 1971, 24, 1093-1095.
LAgRAnge E. \& Bettini S. Descrizione di una nuova filaria, Litomosa Ottavianii Lagrange e Bettini, 1948, parassita di pipistrelli. Rivista di Parassitologia, 1948, 9, 61-77.

LANZA B. I parassiti dei pipistrelli (Mammalia, Chiroptera) della fauna italiana. Monografie 30, 1999, Museo Regionale di Scienze baturali Torino, $318 \mathrm{p}$.

McIntosh A. \& McIntosh G. Additional notes on two bat parasites, Dicrocoelium lasiuri McIntosh, 1933 (Trematoda: Dicrocoeliidae) and Litomosa americana McIntosh, 1932 (Nematoda: Filariidae). Proceedings of The Helminthological Society, 1935, 2, 60-62.

MACKerRAs M.J. Filarial parasites (Nematoda: Filarioidea) of Australian animals. Australian Journal of Zoology, 1962, 10, 400-457.

Moorhouse D.E., Bain O. \& Wolf G. Josefilaria mackerrasae gen. et sp. nov. (Nematoda: Filarioidea) parasite de la Chauvesouris Macroderma gigas Dobson. Annales de Parasitologie Humaine et Comparée, 1979, 54, 645-651.

Ohbayashi M. \& Kamiya H. Nematode parasites from Vespertilio orientalis Wallin. Japanese Journal of Veterinary Research, 1979, 27, 11-15.

OrTLEP R.J. Some Helminths from South African Chiroptera. Report $\left(18^{\text {th }}\right)$ of the Director of Veterinary Services and Animals Industry, Union of South Africa, 1932, 18, 183196.

Peterson R.L., Eger J.L. \& Mitchell L. Chiroptères, in : Faune de Madagascar. Ed. Muséum National d'Histoire Naturelle, Paris, 1995, 84, 1-204.

Petit G. Sur les Filaires du genre Litomosa (Nematoda: Filarioidea), parasites de Chauves-souris. Bulletin du Muséum National d'Histoire Naturelle, Paris, 1980, 4ème série, 2, 365374.

Raharimanga V., Ariey F., Cardiff S.G., Goodman S. M., Tall A., Rousset D. \& RoberT V. Hémoparasites des Chauves-souris de Madagascar. Archives de l'Institut Pasteur de Madagascar, 2003, 69, 70-76.

SEurat L.G. Litomosa filaria Bened., type d'une nouvelle section de Filaires opisthodelphes. Bulletin du Muséum National d'Histoire Naturelle, 1921, 27, 103-106.

SonIn M.D. Osnovi Nematodologii, 24, Filarii, Onchocercini. Academy of Sciences (ed.), Moscow, 1975, 396 p. (in Russian).

Tibayrenc M., Bain O. \& Ramachandran C.P. Deux nouvelles Litomosa (Filarioidea) de Chauves-souris. Bulletin du Muséum National d'Histoire Naturelle, Paris, 1979. $4^{\mathrm{ème}}$ série, 1, 183189.

Trivedi K.K. \& GuptA S.P. Nematodes parasites of vertebrates. A new filariid, Litomosa jairajpuri sp. nov. (family: Dipetalonematidae Wehr, 1935) from a bat, Hipposideros pallidus Blyth from Udaipur Rajasthan, India. Rivista di Parassitologia, 1987 (1989), 48, 315-318.

Wilson D.E. \& ReEDer D.M. Mammals Species of the World: a Taxonomic and Geographic Reference. Second ed. Smithsonian Institution Press, Washington, DC, USA, 1993, 1206 p.

Yorke W. \& MAPLESTONe P.A. The nematode parasites of vertebrates. Churchill J. and A. Ltd, London, 1926, 536 p.

Reçu le 15 novembre 2005 Accepté le 19 décembre 2005 